\title{
Foreign Trade and Its Effects on Nepalese Economic Development
}

\author{
Om Sharma \\ Rajendra Bhandari
}

\begin{abstract}
Having with the objectives of understanding the effects of foreign trade on the economic development process of Nepal, this paper attempts to deal the role and the impact of export and import along with many other pertinent factors. The determining factors that have been considered along with export are: capital stock, labor force, average propensity to save (APS), relative price index (RPI), ratio of government development expenditure to GDP. Moreover, GDP, PCI, and growth rate of GDP are the assumed development indices. These macro variables are introduced through the application of various econometric models. The empirical results have been estimated by applying annual data for the period of 1974/'75 to 2002/'03. The different models in linear and log-linear forms have justified that exports growth leads to economic growth. Therefore, the policy of adequate investment in export oriented industries that embody a 'proper mix' of export promotion and import substitutions is suggested.
\end{abstract}

ECONOMIC DEVELOPMENT IS THE process of economic and social transformation. This process often follows a well-ordered sequence and exhibits common characteristics across countries (Thirlwall 1999). Despite of many constraints- stagnant social and economic situations- urgent economic development is the quest of every nation (Todaro 1997). In the course of struggling with the negative effects of internal and external forces ${ }^{1}$, many countries have been incapable of solving ill socio-economic rigidities and still economically weak to find their development path. Consequently, they are driven in quicksand of poverty, unemployment, inequality and socioeconomic unrest.

Foreign trade is considered as an essential factor for accelerating the path of economic development. Most countries are involved into foreign trade to create employment, raise propensity to save, increase foreign exchange earning, and raise the productivity of investment moving from less productive use to high productive use (Hussain 1996). Because of the benefits of openness, it is settled as the integral part of every country. For developing countries, trade is the primary vehicle for realizing the benefits of globalization. Import brings additional competition and variety of domestic markets benefiting the consumers. Benefiting business, foreign trade gives firms access to improved capital inputs such as machine, tools, boosting productivity as well. Foreign trade encourages the redistribution of labor and capital to relatively more productive sectors. In particular, it has contributed to the ongoing shift of some manufacturing and service activities from industrial to developing countries providing new opportunities for growth (WDR 1999/2000).

World Development Report (1999/2000) highlights that the trade of goods and services has grown twice as fast as global GDP in the 1990's and the share attributable to developing countries has climbed from 23 to 29 per cent. The explosive growth of information

\footnotetext{
${ }^{1}$ Internal forces are supposed to be poverty, unemployment, illiteracy, terrorism, political instability, geographical rigidities, socio-economic unrest etc., External forces are foreign invasion, foreign policies, peripheral location, fixation of quotas etc.
} 


\section{The Journal of Nepalese Business Studies}

and communication technology by 25 per cent between the period 1994- 1997 alone has offered another opportunity for developing countries.

Nepal, a developing country, has profound potential on information technology, which may solve the problem of landlockedness and trade and tariff barrier. The opportunities on garments, carpets and other agriculture and service related productions and good access to herbal production and Ayurvedic medicines can not be overlooked.

Nepalese foreign trade performance has so far been poor. Several factors seem to be responsible, and of these, its landlockedness is one of the major causes for Nepal's weak production base, which is eventually linked with the growth of exports and imports of technology and raw material. Not only the open border with India but also the limited transit facilities in one or other way have constrained its trade with overseas countries. Since transit through china is virtually impractical, India is only economically viable for all commercial flows. Indeed, no country in the world (excluding Bhutan) is so hopeless dependent on the availability of transit facilities from a single country as Nepal (Poudyal 1998). Historically, it is evidenced from almost all trade and transit treaties between these two countries that the transit facilities had in the past always been provided by India in exchange for Nepal's acceptance in giving incentives to Indian goods in Nepalese territories. For this reason, Nepal's trade, especially import trade, in the past virtually had confined to India. Trade with only one partner leaving the options on the basis of comparative advantage virtually obstruct the flow of benefits which is expected to accrue from free trade (Poudyal 98). Naturally, in such a situation, neither foreign trade nor the economy can be expected to have speedy growth.

Foreign trade has however, been rendered due weight in all the periodic plans because of the adverse balance of payment (BOP) position. Realizing that the composition of exports be changed by identifying new exportable, the Ninth Periodic Plan too (1997/'982001/'02) discouraged the import of luxury goods and called for an adequate supply of necessities at reasonable prices. The huge stress has been placed on industrialization through export promotion and import substitution.

Nepal, an agro-based economy, has more than 80 per cent of its people engaged on agriculture profession and the contribution of the agriculture sector to the total GDP constitutes more than 40 per cent (CBS 1999). Since Nepal is least developed in industrial raw materials and highly equipped machinery, there is minimum chance of cost-effectiveness. Small domestic market seems to be an obstacle to economic growth. The world market is then the only readily available way to exploit resources.

The basic problem which arises in managing the world market is environment including different national policies, business customs and practices along with different political and legal formalities and practices, different monetary units, different levels of technology, different cultural and social practices (Shrestha 1994). Therefore, quite different from that of the United States, Japan and European markets, the plan and programs that Nepal prepares, may be ineffective to cope with the different levels of uncertainly encountered in foreign market. Habeler concludes that international trade has made a tremendous contribution to the development of less developed countries in the $19^{\text {th }}$ and $20^{\text {th }}$ centuries and can be expected to make an equally big contribution in the future (Habeler 1959).

Counted in a least developed country of the world, Nepal is bounded on the vicious 
circle of poverty because lumpy amount of people insist in the agricultural professional where the marginal productivity of labor is zero' ${ }^{2}$. To shift the burden from high to low density sector, foreign trade plays the vital role. The same is expected in specialization in production, division of labor, and increase in the national income. Foreign trade also widens the market and increases the inducement to invest income and saving via more efficient resource allocation. The benefits from foreign trade in Nepal may be noted as following. Firstly, trade provides materials, means (capital goods, machinery and raw- and semi-finished materials) indispensable for economic development. Secondly, trade is the means and vehicle for the dissemination of technological knowledge, the transmission of ideas, for the importation of know-how, skill, managerial talents and entrepreneurship. Thirdly, trade is the vehicle for the international movement and capital especially from the developed to underdeveloped countries. Fourthly, free intervention trade is the best antimonopoly policy and best guarantee for the maintenance at a healthy degree of free competition (Meier 1975).

The present study aims to analyze the effects of foreign trade on economic development process of Nepal. Thus, a question arises, whether foreign trade plays significant role in the course of economic development or not?

\section{Delimitation of the Study}

Leaving the earlier period from 1974/'75, this study covers the period FY 1974/75 to FY 2002/2003 because of the inconsistency of the consumer price index. Only quantifiable variables have been given due consideration to analyze the direct effects of trade on the economic development. Indicators like PQLI, Basic need, HDI can be used as dependent variables to measure the development process of a country but the data are unavailable in accordance. Accordingly, GDP and PCI are only accepted as the major dependent variables for measuring the economic development process.

\section{Theoretical Framework}

The problems of underdevelopment are mostly related to poverty, unemployment, low quality of people's lives, low level of capital formation, limited choices of people and mainly of low level of income. Economic development has however, attracted the attention of economists' right from Adam Smith down to Marx and Keynes, yet found mainly interested in the static problems and largely related to the Western European framework. It is however, especially after the Second World War that economists started devoting their attention towards analyzing the problems of underdeveloped countries and formulating theories and models of development ${ }^{3}$. Most development economists are almost unanimous in their view that capital is an essential factor in promoting economic development. Their interest in the eco-

\footnotetext{
${ }^{2}$ The Theory of Unlimited Supplies of Labour propounded by W.A. Lewis: 1950 states that APL determines the wages of labor not by MPL. The surplus labor in traditional sector can be shifted from agriculture to other sectors without reducing the total production.

${ }^{3}$ Harrod - Domar regard capital as a major factor in the development process. Lewis approaches the problem of underdevelopment from the standpoint of technical dualism, disguised unemployment and unlimited supply of labour. Nurkse (1953) identifies a low productive efficiency as a major cause of economic underdevelopment. Rosensetin - Rodan (1961) has developed a big push version of the theory of balanced growth. Hirschman (1958) and Streeten (1959) maintain that growth is largely a function of induced decision making. These theories, by and large, have developed the proposition that capital is a prerequisite of sustained growth.
} 


\section{The Journal of Nepalese Business Studies}

nomics of development has been further stimulated by the wave of political resurgence that swept the Asian and African nations as they threw off the colonial yoke after the Second World War. The view regarding the concept of development indicators has differed. Other than Gross National Product (GNP), Simon Kuznets (1955), Meier and Baldwin (1960) supposed NI as a basic indicator of economic development. Economists like Benjamin Higgins (1999), Harvey Leibenstein (1957), W. Arthur Lewis (1961) and Jacob Viner (1977) take PCI as an indicator of economic development. Presently, human development index (HDI> 0.80) is supposed to be a better indicator.

A great controversy however, lies in regard to the selection of indicators; attentions are laid in accordance to the availability of data. In fact, economic development is the result of secular change in long run. Gold and silver, to Mercantilists, makes a country in well-off situation; increase in national production, to Classicists, is because of profit motive. J.S. Mill (1848) adopts co-operative to increase the welfare of the society and view that laborers overcome from different kinds of domination via co-operative. Marx (1977) advocates socialism as an essential factor for raising maximum welfare. The concept of National Income or Per Capita Income has nevertheless ruled for many years, the now, more emphasis has been given to non-income criteria like basic needs criteria, physical quality of life index$P Q L 1$, and Human Development Index-HDI.

Economic development is the process whereby the real per capita income of a country increases over a long period of time-subject to the stipulations that the number of people below an 'absolute poverty line' does not increase, and that the distribution of income does not become more unequal (Meier 1963; Baron 1957).

Kuznets (1955), Meier and Baldwin (1960), Meade (1972) all have used NI as an appropriate measure of economic development, since per-capita income depends upon the national income. Prof. Meade expects per capita income as the proper medium for providing welfare. Nevertheless, Ahluwalia and et. al (1976) disagree and state "growth rate of GNP in itself is a misleading indicator of development since it is heavily weighted by the income shares of the rich." Though controversial, Morris D. Morris (1979) too asserts Gross National Product (GNP) as the most widely accepted measure of progress.

Modern economists confront with trickle down effect in uplifting the poor so the non-income indicators like physical quality of life index (PQLI) is focused. Morris D. Morris combines three component indicators of infant mortality, life expectancy at age one and basic literacy at age 15 to measure performance in meeting the most basic needs of the people. This index represents a wide range of indicators such as health, education, drinking water, nutrition and sanitation. Though the index is criticized for using arbitrary weights, the PQLI can be used to identify particular regions of under-development and groups of society suffering from the improper social policy. Wherever immediate action is required state can take up such policies that increase the PQL rapidly along with economic growth.

Basic-needs criterion, a substitute of the per capita income, is another yardstick of development, which focuses on alleviation of poverty by providing basic human needs to the poor. The direct provision of health, education, food, water, sanitation and housing affects poverty in a shorter period and with fewer monetary resources than NI and PCI. Life expectancy at birth, literacy, calorie supply per head, infant mortality and percentage of population with access to potable water, infant mortality and percentage of population with 
access to sanitation, and housing are the social indicators for Hicks and Streeten.

The HDI is a simple average of life expectancy index, educational attainment index, and the adjusted real GDP per capita index.

In itself controversial, foreign trade, as advocated by Physiocrates, is a necessary evil because to them both foreign as well as domestic trade produce no real wealth (Roll 1973). Classicist and Neo-classicists regard foreign trade as an engine of growth. Adam Smith's model ${ }^{4}$ of foreign trade postulates the existence of ideal land and labor before a country is opened to world market, his imagination of international man also justify the viability of foreign trade in economic development of any country. In general, classical economists considered comparative advantages as determining the pattern of trade with widening of market, induced innovations, and increase productivity.

Modern economists too pleaded for the gain from the trade, not only change in resource allocation but in continuous impact on economic development of a nation. It stimulates for changing productivity of the economy. Staple's Demand-motored model ${ }^{5}$ and Corden's Supply-motored model ${ }^{6}$ both reveal the positive relation of trade and development emphasizing that the direct gain comes form international specialization.

A country in long run tends to specialize in the production and export of those commodities in which it has comparative advantage (Ricardo 1917). In fact, Eli Heckscher and Bertil Ohlin in Factor Proportion Theory state that the comparative cost differences arise because of two reasons: i. different goods require different inputs, ii, different countries have different factor endowments.

Testing the 'Factor Proportion Theory' empirically, Leontief in 1953 reached the paradoxical conclusion that the United States was the most capital-abundant country in the world. Leontief paradox however, was criticized on the methodological and statistical grounds; various economists applied the model in their study. Tatemoto and Ichimurd discovered Japan as an exporter of capital - intensive and importer of labor - intensive commodities. Stolper and Roskamp concluded that East Germany a labour - intensive country's exports were capital - intensive relative to its imports. Wahl found Canadian exports as capital - intensive relative to the imports. Indian exports were labor-intensive relative to its imports. Nevertheless, Indian exports to the United States were capital-intensive relative to imports. Baldwin found that the U.S. import competing sector was 27 per cent more capitalintensive relative to the U.S. export sector (Qtd. Chacholiades 1978).

Linder's Representative - Demand Hypothesis' states that the income growth affects demand and trade. A rise in per capita income shifts a nation's representative demand pattern towards luxuries that the nation can afford. This new concentration of demand for

\footnotetext{
${ }^{4}$ The model popularly known as "vent for Surplus Theory" assumes resources are not fully employed prior to trade and that are increased without a decrease in domestic production with the result that trade raised the level of economic activity. For detail see "An inquiry into the Nature and causes of the wealth of Nations" ed. Edwin Canaan (1976) p- 415.

${ }^{5}$ Staple's Demand Motored model postulates that with discovery of a primary product in which the country has a comparative advantage, or with an increase in the demand for its comparative advantage commodity, there is an expansion of a resource-based export commodity; this, in turn induces rates of growth of aggregate and per capita income (Qtd. Meier 1995).

${ }^{6}$ W. Max Corden's model emphasizes growth in factor supplies and productivity. After a country is opened to world trade, five effects may appear i.e. impact effect, capital accumulation effect, substitution effect, incomedistribution effect and factor-weight effect.
} 


\section{The Journal of Nepalese Business Studies}

affordable luxury manufacturers causes producers to come up with even more impressive improvements in the technology of supplying those goods in particular (Davis 1985).

Krueger (1978) econometrically tested two hypotheses (1) more liberalized regimes result in higher rates of growth of exports; and (2) more liberalized trade sector has a positive effect on aggregate growth ${ }^{7}$. In the later case, Krueger opines two channels through which openness positively affects growth i. direct effects that operate via dynamic advantages including higher capacity utilization and more efficient investment projects; and ii, indirect effects that work through exports: more liberalized economies have faster growth of exports and these, in turn, result in more rapidly growing GNP. Krueger estimated the following equation on pooled data for traditional and non-traditional exports.

$$
\log X_{i t}=a_{o i}+g \log R E E R X_{i t}+r T_{t}+a_{1} d_{1} T_{t}+a_{2} d_{2} T_{t}+a_{3} d_{1}+a_{4} d_{2}+u_{i t}
$$

Krueger also estimated a real GNP equation on time series for each individual country:

$$
\log G N P_{t}=b_{o}+b_{1} T_{t}+b_{2} \log X_{t}+b_{3} d_{1} T_{t}+b_{4} d_{2} T_{t}+E_{t},
$$

The results strongly confirmed that a more depreciated REERX has a positive impact on non-traditional exports; traditional exports however, did not appear to be sensitive to real exchange rate changes. For both types of exports, the coefficient of $\mathrm{d}_{2}$ - the dummy variable for Phases IV and V- was significantly positive, suggesting that the move to a more 'liberalized' regime also have a positive effect on exports growth. In terms of their relative contributions to export growth, real exchange rate changes appeared to be substantially more important than movements in the liberalization ladder. With respect to GNP growth, the estimates provided strong evidence in favor of an indirect effect of liberalization on growth: higher exports positively affected GNP growth. Shrestha (1981) suggested the need of trade diversification to grab the opportunities of export market. The contribution of processing industries like rice, flour and jute mills was lower than 1.6 per cent of GDP. The gains of trade in terms of introduction of technology were quite low. Continuous rising trend of trade deficit through little change has occurred in export trade.

Tyler (1981) gives empirical evidence demonstrating a cross-country association between export performance and GNP growth. Tyler explains GNP growth with the help of a Cobb-Douglas production function incorporating three productive factors i.e. labor, capital and exports:

$$
\mathrm{Yi}=\mathrm{A} \mathrm{K}_{\mathrm{i}}^{\alpha} \mathrm{L}_{\mathrm{i}}^{\beta} \mathrm{X}_{\mathrm{i}}^{\circ}
$$

Exports are also considered because there are scale-effects and externalities associated with export production and scales ${ }^{8}$. Tyler's regression estimates made with the entire middle income developing country sample disclose that both capital stock and exports make considerable contribution to GDP growth.

Pokherel (1982) finds that the volume of imports from other countries was galloping year after year while volume of export was not increased in the same direction. The study was able to show the significant relationship between the growth of Nepalese overseas trade and the growth of her GDP, growth of Nepalese exports to overseas and growth of her import from overseas. Ligal (1983) considers a simple Keynesian macro framework to show

\footnotetext{
${ }^{7}$ A liberalized regime is one that had reduced the extent of anti-exports bias.

${ }^{8}$ Because of export market competition, non-exported products may tend to be produced more efficiently. Moreover, allocation gains may be captured through greater export activity. LDCs can achieve a wider use of abundant labour resource and a fuller use of existing capacity with increased international specialization along comparative advantage (Tyler 1981-125)
} 
the relationship between GDP and other related variables. Beta co-efficient ${ }^{9}$ is used to determine the importance of government expenditure on imports, prices and money supply and Hansen Stabilization Index ${ }^{10}$ has been used to measure the stabilizing or destabilizing character of expenditure policy. The application of multiple regressions justified the significant government expenditure with negative and insignificant coefficient of GDP along with insignificant domestic price level. Feder (1983) provides the formal model to show significant relationship between exports and growth of GDP i.e., $y=N+X$, where $\mathrm{X}$ is exports sectors and $\mathrm{N}$ is non-exports sectors ${ }^{11}$. Then $\mathrm{N}$ is defined as $N=F\left(K^{n}, L^{n}, X\right)$ and $\mathrm{X}$ is defined as $X=G\left(K^{x}, L^{x}\right)$, where $\mathrm{K}^{\mathrm{i}}$ and $\mathrm{L}^{\mathrm{i}}$ are capital and labour used in $\mathrm{i}(\mathrm{i}=\mathrm{N}, \mathrm{X})$ sectors. Assuming marginal productivity of labor equal to $\beta(y / L)$ where $\beta$ is constant; Feder derives the following equation for the rate of growth of GDP:

$(y / y)=\alpha(I / Y)+\beta L / L)+\{F x+(\delta /(I+\delta))\}(\dot{\mathrm{X}} / \mathrm{X}) .{ }^{12}$, where $(\mathrm{I} / \mathrm{Y})$ is the investment ratio,

$\mathrm{L} / \mathrm{L}$ is growth rate of labor force and $(\dot{\mathrm{X}} / \mathrm{X})$ growth rate of export, $(1+\delta)=\left(\mathrm{G}_{\mathbf{k}} / \mathrm{F}_{\mathrm{k}}\right)=\left(\mathrm{G}_{\mathrm{L}} /\right.$ $F_{L}$ ) and $G_{L}, F_{L}$ are marginal productivity of labour and $G_{K}, F_{K}$ are the marginal productivity of capital. Feder uses a sample of 31 semi-industrialized countries and estimates that the marginal factor productivity in exports sectors are higher than in the non-export sector.

Kovoussi (1984) shows the effect of export growth on total factor productivity through an inter country regression analysis by the application of a simple production function:

$$
Y_{t}=F\left[K_{t}, L_{t}, t\right] \quad \ldots \ldots \ldots(I)
$$

Assuming disembodied technical progress, the elasticity of output with respect to capital and labor force is constant and technical change (Hicks-neutral) and its rate remains unchanged. The growth rate of GNP may be expressed as:

$$
R Y=a+b R K+c R L
$$

The hypothesis, that export expansion increases the growth of total factor productivity, can be introduced in the model assuming the rate of technical change as a linear function of the growth rate of exports $(\mathrm{RX})$. Hence,

$$
R Y=a+b R K+c R L+d R X
$$

Kavoussi considers average annual growth rates of GNP, capital stock, labour force and exports between 1960 and 1978 for estimating (II) and (III) models. In both low-and middle-income countries, the coefficient of RX is positive and highly significant, indicating

\footnotetext{
$\overline{9}$ Beta co-efficient of government expenditures is defined as Beta $\boldsymbol{g}=\boldsymbol{b g}(\boldsymbol{Q g} / \mathbf{Q z})$, where bg=regression coefficient of government expenditure on price or money supply or imports, $Q g=$ standard deviation of G, $\mathrm{Qz}=$ standard deviation of $\mathrm{P}, \mathrm{M}$ or Ms.
}

$101\left(1-\sum \mathrm{z}_{\mathrm{t}} / \sum_{\mathrm{t}}^{\mathrm{t}} \mathrm{z}_{\mathrm{t}}\right) \cdot 100$, where $\sum^{t} z_{t}=$ sum of $\mathrm{M}$ or $\mathrm{P}$ or MS.

11 Export contributes to aggregate output in two fundamental ways: first it is assumed that the exports sector generates positive externalities on non exports sectors, through more efficient management styles and improved production techniques. Second, there is a productivity differential in favour of the exports sector.

12 Derived from $y=N+X, N=F\left(K^{n}, L^{n}, X\right), X=G\left(K^{x}, L^{x}\right)$ and the assumption that $F L=\beta(y / L)$, where $\beta$ is constant and $\alpha$ equals to $\mathrm{F}_{\mathrm{K}}$. 


\section{The Journal of Nepalese Business Studies}

the major role of export expansion in influencing the growth of total factor productivity. Since a larger percentage of exports in middle-income countries is composed of manufactured products, the higher coefficient of RX in this sub sample means that the effect of manufactured exports on factor productivity is greater than that of primary products. To prove this, the coefficient of RX is expressed as a linear function of the commodity composition of exports.

$$
R Y=a+b R K+c R L+\left(d_{1}+d_{2} M X\right) R X \quad \ldots \quad \ldots \ldots(I V)
$$

where, MX represents the share of manufactured goods in total merchandise exports, $\mathrm{d} 1$ is the coefficient of RX when $\mathrm{d}_{2}$ is zero (that is, exports comprise only primary goods, and not manufactured goods) the share of manufactured goods in total exports (at the end of the period) is zero and $d_{1}+d_{2} M X$ is the coefficient of $R X$ when the share of manufactured goods in total exports is MX per cent.

For estimating $\mathrm{d}_{1}$ and $\mathrm{d}_{2}$ equation IV is expressed as:

where, $\mathrm{MRX}=(\mathrm{MX})(\mathrm{RX})$

$$
R Y=a+b R K+c R L+d_{1} R X+d_{2} M R X
$$

The results reveal that the impact of commodity composition of exports is quite different among low and middle-income countries. Furthermore, export expansion on the growth of total factor productivity has been very sensitive to the share of manufactured goods in total exports for middle-income countries.

Applying the production function approach with the growth rate of export, Balassa (1985) introduced per capita income to show the impact of the level of development on economic growth. Taking into account 43 countries that were adversely affected by external shocks after 1973, the coefficient of the growth rate of export $\left(\mathrm{X}_{\mathbf{i}} / \mathrm{X}_{\mathrm{i}}\right)$ was experienced higher during the period 1973-79 than to the earlier.

As others, Ram (1985) also tested the production function framework on 73 countries for te periods 1960-70 and 1970-77 and found that the coefficient of growth rate of export was significantly positive and remained higher in lateral period. In addition, Ram (1987) urther applied the aforementioned approach on time series and cross sectional data by dividing the sample population into "before oil shock" and "after oil shock"; and between low and middle-income countries. In vast majority of cases the estimated coefficient of export growth for the 1973 - '82 periods was found smaller than those were for earlier period.

Applying the Keynesian model, Khanal (1988) arrives at the necessity of adopting strong discretionary and control measures (different tariff and taxation measures accompanied by foreign exchange regulation). Gray and Singer (1988) used Kavoussi's expots decomposition technique and found Spearmans' rank coefficient as positive and significant for countries facing above the average of world demand whereas insignificant for those facing below the world demand conditions. Commenting the work of Balassa, Rana (1988) considers balanced sample of 43 nations for before and after 1973. All the estimates of the growth rate of export were significantly positive and smaller for post-1973 period than those for earlier period.

In his study 'Foreign Trade, Aid and Development in Nepal'Poudyal (1988) analyses the relationship between GDP and investment, GDP and foreign aid, and import and GDP with the framework of Almond Polynomial lag scheme. These relations are expected to follow an inverted U-type lag pattern. In the case of imports, the behavior out of equilibrium is also examined in the framework of a partial adjustment model, corresponding to a geometrically declining lag structure. Considering the study period, 1964 /'65 to 1981/'82, 
the import equation in the linear form is expressed as:

$$
M_{t}=a_{0}+a_{1} Y_{t}+a_{2}\left(P_{r_{0}} / P_{d}\right)_{t}+U_{t} \text { where } a_{1}>0, a_{2}<0 .
$$

The same equation has been also tested on logarithmic and lagged forms. The twogap model and different structural equations were set out to deal with the problem of constraints for development process of Nepal alike:

$$
\mathrm{Y}_{\mathrm{t}}^{*}=\mathrm{Y}_{0}\left(1+\mathrm{r}^{*}\right)^{\mathrm{t}}, \mathrm{X}_{\mathrm{t}}^{*}=\mathrm{X}_{0}(1+\mathrm{e})^{\mathrm{t}} \text { and } \mathrm{M}_{\mathrm{t}}^{*}=\mathrm{r}
$$

The forecasts with the help of Two-Gap model have justified that the trade gap would be the binding constraint in Nepal's development all through the next 15 years.

Kohli and Singh (1989) have used Feder's model to see the relationship between export growth and GDP growth considering 41 countries as the sample for the period 1960 to '70 and 1970 to '81. Coefficient of the growth rate of export has been found as significant for the period 1960 - '70 and insignificant for the period 1970 - ' 81 . In the process of analyzing the relationship between export and growth process of Nepal, Regmi (1998) concludes that export plays a tremendous role of expanding the pace of economic development in general and create to robust industrial sector in particular. The unsuccessfulness of the government policies led Devkota (2000) to suggest the government to increase export by mobilizing the domestic resources. Mainly concentrated on impact of exchange rate change on foreign trade balance, due consideration has been given onto import and export functions ${ }^{13}$ in two categories i.e. India and rest of the world. In fact, Nepalese exchange rate devaluation is not the proper method of correcting the trade deficit (Garanja 2000). Moreover, Poudyal (1998) examines the impact of foreign trade on economic growth of Nepal. Export / GDP, Import / GDP, Balance / GDP and Export / Import ratios have been used to analyze the condition of trade of Nepal since 1974 / 75 to 1994 / 95. Growth of GDP at market price has been an important indicator to observe economic growth of a country. The concept of multiplier, $K=1 /(m p s+m p m) * d x$, is used and derived 1.47. The multiplier effect of the export trade seems weak in Nepal because of adverse terms of trade. The multiplier effects on the output growth have revealed foreign trade as a decisive player in the process of economic development of the country. Furthermore, author gives remarks that Nepal's foreign trade has tremendously been suffering from growing trade deficit, which can have negative impact on the

${ }^{13} \boldsymbol{M}_{t}=\boldsymbol{f}\left(\boldsymbol{N G D P}, \boldsymbol{R E E R}, \boldsymbol{M}_{t-1}\right)$, and $X t=f(N G D P, R E E R, X t-1$ where NGDP is Nominal Gross Domestic Product, $\boldsymbol{R E E R}$ is Real Effective Exchange Rate, $\boldsymbol{M}_{t}$ is imports in the year $\boldsymbol{t}, \boldsymbol{X}_{\boldsymbol{t}}$ is exports in the year $\mathrm{t}$ and $\boldsymbol{X}_{t-1}$ and $\boldsymbol{M}_{t-I}$ are exports and imports in the year $\mathrm{t}-1$.

${ }^{14}$ Chenery (1960) defines import substitution as the difference between growth in output with no change in the import-ratio and the actual growth. The magnitude of import substitution between two periods 1 and 2 IS=IS=

$$
I S=\frac{\left(\sum_{i=1}^{n} Q_{2}^{i} / \sum_{i=1}^{n} S_{2}^{i}\right)-\left(\sum_{i=1}^{n} Q_{1}^{i} / \sum_{i=1}^{n} S_{1}^{i}\right) \cdot \sum_{i=1}^{n} S_{2}^{i}}{\sum_{i=1}^{n} Q i}
$$

${ }^{15}$ Desai (1969) says two types of import substitution measures prevail (a) those referring to some notion of optimality, and, (b) those that are purely descriptive of changes in the actual pattern of imports and domestic production.

${ }^{16}$ Fane (1973) portals import substitution for industry is evaluated in two parts: (a) import substation within the industry (Mi) and the extra contribution, $\mathrm{M}$ is growth in industry I to import substitution, Therefore, $\mathrm{M}^{\mathrm{T}}=\mathrm{M}+\mathrm{M}_{\mathrm{i}}$. For details see Pant (1994), Trade and development. 


\section{The Journal of Nepalese Business Studies}

economy as a whole. Pant (1994) takes concern with the import substitution measures of Chenery, ${ }^{14}$ Desai, ${ }^{15}$ and Fane ${ }^{16}$. At the juncture of the analysis, the study has found significant impact of manufactured export on the economic development process of Nepal. Greater technological progress is required for total export growth to enhance the total factor productivity regardless of the composition of exports. The import substitution policy adapted by the government demands overall evaluation and analysis. While concluding, Pant firmly speaks that the Nepalese policy makers should develop a trade strategy that embodies a 'proper mix' of the export promotion and import substitution.

\section{Research Methodology}

A research design is the arrangement of conditions for collection and analysis of data in a manner that aims to combine relevance to the research purpose with economy in procedure (Selltitz, and et al 1976). It is a known fact that the econometric analysis of the Nepalese economy is severely inhibited by a wide range of scientific data deficiencies. As in many developing countries but probably even more in Nepal, planning is severely handicapped by the dependable data in sufficient quantity (Barkay 1982). In view of the poor database, a rigorous quantitative analysis of the macro-economic relationship for the Nepalese economy may not be feasible and even justified. However, a beginning, howsoever inadequate, must be made somewhere with whatever data it is possible to compile. However as an alternative, though not a satisfactory way to do, value of relevant variables are converted to constant prices by means of single GDP deflator.

This study is based on secondary data sources. Various published reports, surveys, bulletins and journals were consulted to collect the data. Important among them are Economic Surveys 1998/99 and 2003/04, NRB's Quarterly Economic Bulletin, 2002, various Censuses, International Financial Statistical Year Book, 1987 and Economic \& Political Weekly 2004, CBS's Statistical Year Books. Absence of data tempted the researchers to apply the methods of data filling i.e., extrapolation \& intrapolation.

Considerable effort has been made to standardize the data, but full comparability cannot be assured, and care must be taken in interpreting the indicators. Statistical systems in many developing economies are still weak; statistical methods, coverage, practices and definitions differ widely; and cross-country and inter-temporal comparisons involve complex technical and conceptual problems that cannot be unequivocally resolved (WDR 2003).

\section{Models}

Due consideration has been given to the models applied by Tyler (1981), Feder (1983) Balassa (1985) so as to click the relationship between export expansion and economic growth along with the linear and log-linear forms of the import function. The model of Tyler (1981), based on a Cobb-Douglas production function considers the factors such as GDP, capital $(\mathrm{K})$, and labor (L) and exports (X). It also comprises factors like annual growth rate of capital (GRK), labor (GRL) exports (GRX) and manufactured exports (GRXM) as independent variables. Per Capita Income (PCI), Annual growth of GNP (GRY) have also been employed as dependent variables. Replacing saving instead of capital employs the models of Balassa (1985) and Tyler (1981). The models of various forms are listed as follows:

Linear Form: $G D P=A+\alpha K+\beta L+\chi X$ 


$$
\begin{gathered}
\alpha>0, \quad \beta>0, \chi>0 \\
G D P=A+\alpha S+\beta L+\chi X \\
\alpha .>0, \quad \beta>0, \quad \chi>0 \\
P C I=A+\alpha K+\beta L+\chi X \\
a .>0, \beta>0, c>0 \\
M=n_{0}+n_{1} A P S+n_{2} G D E G D P R+n_{3} R P I . \\
n_{1}>0, n_{2}>0 n_{3}<0
\end{gathered}
$$

Log-Linear Form: $\ln G D P=\ln A+\alpha \ln K+\beta \ln L+\chi \ln X$.

$$
\begin{gathered}
\alpha \cdot>0, \beta>0, \chi>0 \\
\ln G D P=\ln A+\alpha \ln S+\beta \ln L+\chi \ln X .
\end{gathered}
$$$$
\alpha .>0, \beta>0, \chi>0
$$$$
\ln P C I=\ln A+\alpha \ln K+\beta \ln L+\chi \ln X \text {. }
$$$$
\alpha .>0, \beta>0, \chi>0
$$$$
\ln M=\ln n_{0}+n_{1} \ln A P S+n_{2} \ln G D E G D P R+n_{3} \ln R P I .
$$

Growth Rate Form: GRY $=A+\alpha G R K+b G R L+c G R X$.

- Cobb-Douglas Form: GDP $=A K^{\alpha} L^{\beta} X^{\alpha}>0$

$$
\alpha .>0, \beta>0, \chi>0
$$

$$
\begin{aligned}
& G D P=A S^{\alpha} L^{\beta} X^{\circ} \\
& P C I=A K^{\alpha} L^{\beta} X^{\circ}
\end{aligned}
$$

Feder's (1983) model is considered to show the relationship between growth rate of export and growth rate of GDP, which is expressed as:

$$
\text { - GRY }=A+\alpha R I G D P R+\beta G R L+\{F x+(\delta /(1+\delta))\} \chi G r \text {. }
$$

Where $\delta$ and Fx signify the coefficient of productivity differential and export related externalities respectively.

Furthermore, the linear and log-linear models are employed to see the relationship of imports to aggregate private spending (APS), ratio to government development expenditure to GDP (GDEGDPR), foreign aid (FAID), GDP, population, and relative price Index of Nepal to India (RPI).

\section{Empirical Results}

Foreign trade, as an engine of growth during $20^{\text {th }}$ century, has not been so popular. In fact, the implementation of industrialization policies then was of limited degree of international openness. The Import Substitution Industrialization (ISI) strategy of Raul Pervish (1950) and Hans Singer (1950) emerged as viable. Indeed, the debt crisis unleashed in 1982 played a consequential role in reshaping policy views regarding development strategies, growth policy and long-term growth. In this regard Edwards (1993) remarks "In the 1980s, economists dealing with poorer nations began to recommend, with increasing insistence, the development strategies based on market oriented reforms that included as a fundamental component, the reduction of trade barriers and the opening of international trade to foreign competition".

Although, East Asian countries seem to be successful in the field of development through foreign trade still controversies remain. In the judgement of the beneficial effects of foreign trade, most empirical studies are found to be directed to the direct impact of export growth in national income and saving. The studies of Krueger (1978), Tyler (1981), Feder 
(1983), Balassa (1985), Gray and Singer (1988), Kohli and Singh (1989), Esfahani (1991), Kovoussi (1984) sought the direct impact of export growth on output growth in a country.

The answer of the query sets forth the issue, do countries with rapidly growing export, have a higher rate of aggregate growth, or is it that faster growing countries have more dynamic export sector? Bearing this in mind, Gross Domestic Product (GDP) and annual percentage growth rate of Gross Domestic Product (GRY) at current as well as constant prices are assumed as dependent variables. Capital (K), Labor (L), Export (X), annual percentage growth of capital (GRK), annual percentage growth of labor (GRL), annual percentage growth of export (GRX) and annual percentage growth of manufacturing export (GRXM) both in current and constant prices are applied as independent variables. The results of the linear and the log-linear models are stated as:

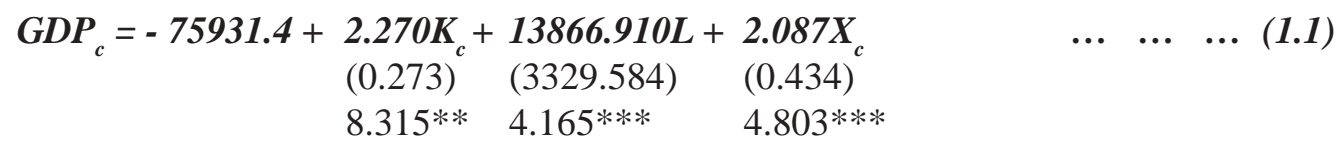

$$
\begin{aligned}
& \mathrm{R}^{2}=0.996, \mathrm{SEE}=9611.215, \mathrm{~F}=1910.085, \mathrm{DW}=1.896 \\
& \text { In } G D P_{c}=2.619+0.539 \operatorname{In} K_{c}+0.890 \operatorname{In} L+0.191 \operatorname{In} X_{c} \text {. } \\
& \begin{array}{lll}
(0.414) \quad(0.414) \quad(0.041)
\end{array} \\
& 5.960 * * * \quad 2.151 * * \quad 4.620 * * *
\end{aligned}
$$

$\mathrm{R}^{2}=0.998, \mathrm{SEE}=0.05415, \mathrm{~F}=4176.262, \quad \mathrm{DW}=1.519$

The examinations of the commonly used regressions in fact, confirm a priori notion in terms of both sign and magnitude. The coefficients of capital, labor and export play dominant role in raising current level of gross domestic product (GDP). In so far as export is concerned, the log-linear equation shows that, other things remaining same, export leads to increase GDP by 19.1 per cent. The absence of serial correlation (DW $>$ upper limits $\mathrm{d}_{\mathrm{U}}=1.42$ ) along with the fulfillment of all the statistics, justify the reliability and the validity of the models. In the course of analysis, the same log-linear model in constant price, has detected the serial correlation and is excluded from the test. ${ }^{17}$ Similar results are observed when export is included in the Cobb-Douglas form. The results are expressed in the following equation.

$G D P_{C}=13.7219 K^{(1.714)} L^{(2.435)} X^{(1.210)}$

The efficiency parameter and elasticity coefficients are both in positive sign and magnitude that refer to the validity of the model. Along with capital and labor, export elasticity seems to be more sensitive ( $\mathrm{e}>1.21$ ). A hundred per cent change in export leads to 121 per cent change in GDP. The Cobb-Douglas model exhibits the higher elasticity of independent variables than log-linear one. In the same framework of the model, saving has been replaced instead of capital and the results are:

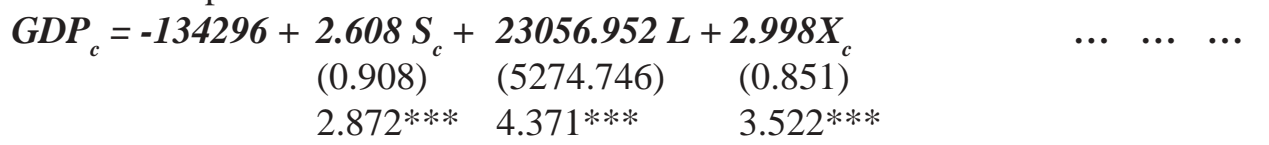

$$
\begin{aligned}
& \mathrm{R}^{2}=0.988, \mathrm{~F}=669.113, \mathrm{SEE}=16173.816, \mathrm{DW}=0.989
\end{aligned}
$$

Although, the aforementioned model seems to be good fit, it is not free from serial 
correlation and bears large standard of error. Therefore, auto-correlation needs to be corrected. Even after applying remedial measures, the model inherits serial correlation and therefore excluded. In the constant price data, same model has been computed and the results obtained are :

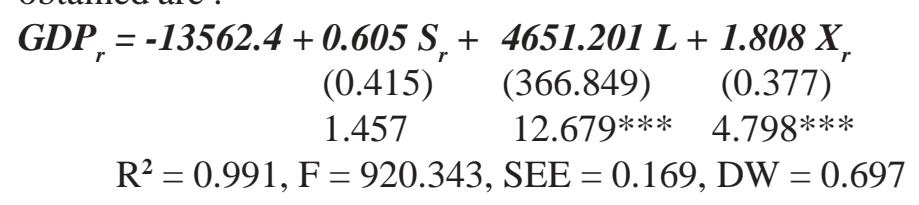

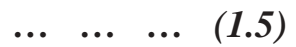

The reliability and validity of the model is higher in constant price because of higher $\mathrm{R}^{2}$ and lower SEE. The sign and magnitude of the model is according to the hypothesis, $\mathrm{t}$ and $\mathrm{F}$ statistics are significant for labor and export, but $\mathrm{t}$-value is insignificant for saving. After the treatment of serial correlation, the following result is obtained.

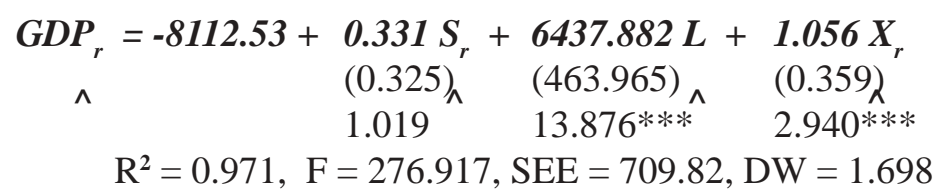

Though, the explanatory power of the model decreases slightly and SEE is higher than equation (1.5), the model can be said good fit since it is free from serial correlation. The results depict that labor force and exports are highly significant in determining real GDP of Nepal. The positive coefficient of saving however, remains as insignificant, does not violate the assumption of the model. The marginal propensity to export is more than unity but of saving less. The results of log-linear form may be expressed as:

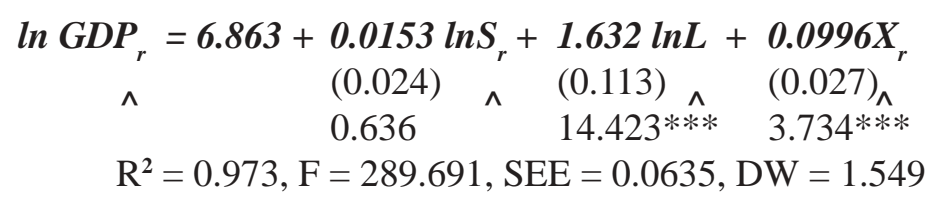

Higher $\mathrm{R}^{2}$ and lower SEE confirm that log-linear model is more reliable than linear one similar to the earlier models. The coefficient of saving is insignificant. Labor force $(\mathbf{e}=\mathbf{1 . 6 3 2})$ is found more elastic than exports $(\mathbf{e}=\mathbf{0 . 0 9 9 6})$. Positive sign and magnitude of the coefficients, lower error and highly significant t-values depict that export is more viable factor to determine the real GDP of Nepal. The Cobb-Douglas form as expressed

$$
G D P_{r}=956.231 S_{r}^{(1.015)} L^{(5.114)} X_{r}^{(1.104)} \quad \ldots \ldots
$$

in the equation 1.8, no doubt envisages elasticity coefficients and efficiency parameter both in positive sign and magnitude that reveals the validity of the model. Elasticity coefficient of export is greater than unity $(\mathbf{e}=\mathbf{1 . 1 0})$. It depicts one per cent change in export leads to $1.1 \mathrm{per}$ cent change in GDP. The Cobb-Douglas model shows the higher elasticity of independent variables than log-linear model.

Assuming per capita income as one of the indicators of development, the aforesaid models have been reexamined where; labor, capital and exports are considered as independent variables. The results are given in the Table. 1 


\section{Table 1 : Regression Results: 1974/'75 to 2002/'003}

\begin{tabular}{|c|c|c|c|c|c|c|c|c|c|}
\hline Equ. & Depen & Intercept & Regression & fficients & & $\mathrm{R}^{2}$ & $\mathrm{~F}$ & SEE & D.W \\
\hline 1.9 & $\mathrm{PCI}_{\mathrm{c}}$ & -5772.086 & $\begin{array}{l}1110.051 \mathrm{~L} \\
(198.996) \\
5.58 * * *\end{array}$ & $\begin{array}{l}0.0889 \mathrm{~K}_{\mathrm{c}} \\
(0.016) \\
5.45^{* * *}\end{array}$ & $\begin{array}{l}0.0541 \mathrm{X}_{\mathrm{c}} \\
(0.026) \\
2.09 * * *\end{array}$ & 0.991 & 936.48 & 574.42 & 0.81 \\
\hline 1.10 & $\mathrm{PCI}_{\mathrm{c}}$ & -541.905 & $\begin{array}{l}2367.94 \hat{\mathrm{L}} \\
(322.142) \\
7.351 * * *\end{array}$ & $\begin{array}{l}0.0341 \hat{\mathrm{K}}_{\mathrm{c}} \\
(0.014) \\
2.428 * *\end{array}$ & $\begin{array}{l}0.0725 \hat{X}_{c} \\
(0.021) \\
3.430 * * *\end{array}$ & 0.980 & 408.14 & 353.90 & 1.69 \\
\hline 1.11 & $\mathrm{In} \mathrm{PCI}_{\mathrm{c}}$ & 1.599 & $\begin{array}{l}1.821 \ln \hat{\mathrm{L}} \\
(0.458) \\
3.972 * * * \\
\end{array}$ & $\begin{array}{l}0.317 \ln \hat{\mathrm{K}}_{\mathrm{c}} \\
(0.067) \\
4.700 * * * \\
\end{array}$ & $\begin{array}{l}0.143 \ln \hat{X}_{\mathrm{c}} \\
(0.038) \\
3.738 * * * \\
\end{array}$ & 0.99 & 823.51 & 0.09 & 1.91 \\
\hline
\end{tabular}

Notes: *** refers significant at $1 \%$ level of significance ** refers significant at $5 \%$ level of significance * refers significant at $10 \%$ level of significance. ${ }^{\wedge}$ refers model in first difference form.

The linear model (1.9) needs further process of evaluation due to the presence of auto- correlation though all the statistics are significant with positive sign and magnitude except DW test. The regression model 1.10 reveals correct Durbin Watson value, higher $\mathrm{R}^{2}$, lower SEE in comparison to the equation (1.9) signifying the reliability and validity. Labor and exports are significant at 1 percent and capital on 5 per cent level of significance. Circumstances throw light on the fact that labor, capital, and exports all confer positive role in determining per capital income of Nepal. In view of the result of the log-linear model (1.11), the elasticity of labor has been found more than unity. However, of capital and exports, the elasticity coefficients exhibit to increase in per capital income by about 32 and 14 per cent, respectively. Similar to the earlier application, the Cobb-Douglas form of model provides the following results.

$P C I_{c}=4.9481 L^{(6.178)} K^{(1.373)} X^{(1.153)}$

The efficiency parameters and elasticity coefficients both have positive signs. This confirms the validity of the model. The elasticity coefficient of export greater than unity shows that a unit increase to exports leads to increase per capita income by more than unity. Thus, it is evident that export has significant role in raising per capita income of Nepal. The temptation of testing the hypothesis in the framework of growth rate equation remained further. Annual percentage growth rate of labor (GRL), capital (GRK) and annual percentage growth rate of export (GRX) at current price have been taken as independent variables. The regression results in both current and constant prices are as follows:

$$
\begin{aligned}
& G R Y_{c}=13.158-1.433 G R L_{c}+0.0585 G R K_{C}+0.109 G R X_{c} \\
& \begin{array}{lll}
(1.479) \quad(0.081) \quad(0.037)
\end{array} \\
& \begin{array}{lll}
-0.969 & 0.725 & 2.926 * * *
\end{array}
\end{aligned}
$$

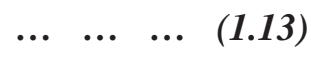

$$
\begin{aligned}
& \mathrm{R}^{2}=0.329, \mathrm{SEE}=4.7652, \mathrm{~F}=4.086, \mathrm{DW}=1.519 \\
& G R Y_{r}=3.892-0.163 G R L_{r}-0.011 G R K_{r}+0.084 G R X_{r} \\
& \begin{array}{lll}
(0.0683) & (0.041) \quad(0.019)
\end{array} \\
& -0.238 \quad-0.275 \quad 4.396^{* * *} \\
& \mathrm{R}^{2}=0.443, \mathrm{~F}=6.628, \mathrm{SEE}=2.2214, \mathrm{DW}=2.279
\end{aligned}
$$

Negative coefficient of $\mathrm{GRL}_{\mathrm{C}}$ seems to be plausible in the context of growing unemployment in the country, which means highly growing labor force leads a decrease in 
GDP growth, quite similar to the theory derived by Lewis (1961). Positive but insignificant coefficient indicates that the growth of capital stock does not have considerable effect on the percentage growth of income. The ineffectiveness of the rate of growth of capital seems to be due to the capital dependency towards foreign countries. The positive coefficient and significant $\mathrm{t}$-value of $\mathrm{GRX}_{\mathrm{C}}$ or, the export expansion has significant effect in the growth of GDP. However, the explained percent of variation $\left(\mathrm{R}^{2}=0.33\right)$ seems to be less, F-value significant at 5 per cent level, less SEE and the absence of auto correlation shows the greater reliability of the sampling distribution. As far as the growth rate of income is concerned, the model is to be considered as a grain of salt. In constant price data, the same model turns to be different and the explanatory power of the model has increased to 44 per cent. Despite the negative sign and magnitude, however, insignificant impact of the growth rate of labor and capital, growth rate of exports has been found positive and significant in raising GDP of Nepal.

Although, primary exports and manufacturing exports confluence, the study incorporates manufactured exports to show the impact on economic growth. The following result is obtained by regressing GDP growth with growth of capital, labor and manufactured exports at current price.

$$
\begin{aligned}
& G R Y_{c}=14.611-1.701 G R L+0.033 G R K_{C}+0.059 G R X M \\
& \begin{array}{ccc}
(1.622) & (0.095) & (0.036) \\
-1.049 & 0.358 & 1.672 * \\
\mathrm{R}^{2}=0.190, \mathrm{SEE}=5.236, \mathrm{~F}=1.952, \mathrm{DW}=1.80
\end{array} \\
& \begin{array}{ccc}
(1.622) & (0.095) & (0.036) \\
-1.049 & 0.358 & 1.672 * \\
\mathrm{R}^{2}=0.190, \mathrm{SEE}=5.236, \mathrm{~F}=1.952, \mathrm{DW}=1.80
\end{array} \\
& \begin{array}{ccc}
(1.622) & (0.095) & (0.036) \\
-1.049 & 0.358 & 1.672^{*} \\
\mathrm{R}^{2}=0.190, \mathrm{SEE}=5.236, \mathrm{~F}=1.952, \mathrm{DW}=1.80
\end{array}
\end{aligned}
$$

With the replacement of manufactured exports growth, only 19 per cent of the variance in income growth rates is explained by the rates of growth of capital stock, labor force, and manufactured exports. With the assumption of Hicks neutral technological progress, the constant in the regression estimates presents an estimate of annual average technological progress (Tyler 1981). It is observed that the technological progress is measured high in the equation where manufactured export has been included.

As the capital and exports have been replaced by investment GDP ratio (i.e. average propensity to invest) and the product of export growth and export GDP ratio (i.e. XG) in current price data the model turns as:

$G R Y_{r}=A+\alpha R I G D P R+\beta G R L+\left[F_{X}+(\delta / 1+\delta)\right] X G_{r}$

Instead of export growth, the product of export growth and the ratio of exports to GDP, that is, $\mathrm{XG}$ is introduced to separate the effect of exports on economic growth into two parts: productivity differential due to difference between exports and non-exports and externalities generated by exports. Capital growth is replaced by the average propensity to invest in constant price, which is more plausible to determine GDP growth. The presence of the export's growth term on the right hand side of the equation (1.16) distinguishes this expression from a straightforward growth accounting equation. It is noticed that in the absence of productivity differential $(\mathrm{d}=0)$ and of export related externalities $(\mathrm{Fx}=0)$, the GRX term disappears, and equation reverts to a neoclassical growth equation. ${ }^{18}$ The results restated as:

$$
\begin{aligned}
& G R Y_{r}=3.593+0.0042 R I G D P R-0.0807 G R L+0.0087 X G_{r} \\
& (0.210) \\
& 0.020 \\
& \text { (1.339) } \\
& -0.018 \\
& (0.003) \\
& 2.983 * * * \\
& \mathrm{R}^{2}=0.272, \mathrm{SEE}=2.5391, \mathrm{~F}=3.119, \mathrm{DW}=2.438
\end{aligned}
$$

\footnotetext{
${ }^{18} \mathrm{GRY}_{\mathrm{r}}=\mathrm{A}+\alpha \mathrm{RIGDPR}+\beta \mathrm{GRL}+[\mathrm{FX}+(\delta / 1+\delta)]$ GRX. XGDPR.
} 
In aforementioned model, the main hypothesis being tested is whether the coefficient of $\mathrm{XG}_{\mathrm{r}}$ variable is significantly positive as suggested by theory or not. Though the explained percent of variation is low, all other necessary statistics reveal reliability of the model to some extent. The positive and significant coefficient of XGr tells the truth that the marginal factor productivity is higher in the export sector than in non-export sector. The cause behind this could be the more competitive environment in which export oriented firms operate (Feder 1983). Not only negative but also insignificant coefficient of the growth rate of labor force entails that it is unimportant factor in determining the growth rate of annual income. However, positive in sign and magnitude, RIGDPR demonstrates insignificant impact of investment GDP ratio on economic growth of Nepal. At this conjecture, it is concluded that the linear and log-linear forms of the models have yielded satisfactory results. Therefore, beside labor and capital growth, exports are highly associated with that of GDP of Nepal.

The study of foreign trade is incomplete until addressing import. Nepal, a developing country has greater weightage of import than export. It is generally stated that the import of more goods and services does more harms than goods in view of the assumption of favorable balance of trade. This statement creates doubt and is inapplicable fully to country like Nepal. Since Nepal's major exports is determined by importation of good and services, for example, the garment and carpet industries. Similar situation does exist for tourism. An attempt also has been made to test the import function of Nepal in linear and log linear form both in current and constant price data.

In the models, all the variables have been considered in current as well as constant prices. Average private spending [APS = GDP-G- $(\mathrm{X}-\mathrm{M})$ ], the ratio of government development expenditure to GDP (GDEGDP), foreign aid (FAID), population (POP), time $(\mathrm{T})$, and relative price index $(\mathrm{RPI}=$ wholesale price index of India/Consumer price index of Nepal) are taken as independents. It is important to state that the application of the multiple regression on forward criterion has removed the predictors such as RPI, GDEGDP and population. In fact, the tolerance factor for removed variables is found low which in turn has yielded high value inflated factor. The results are as follows.

Table 2 : Linear Regression Models of Current Prices (1974/'75-2002/'03)

\begin{tabular}{|c|c|c|c|c|c|c|c|c|c|c|}
\hline \multirow[t]{2}{*}{ Equ. } & \multirow{2}{*}{\multicolumn{2}{|c|}{ Depen Intercept }} & \multicolumn{4}{|c|}{ Regression Coefficients of } & \multirow[t]{2}{*}{$\mathrm{R}^{2}$} & \multirow[t]{2}{*}{$\mathrm{F}$} & \multirow[t]{2}{*}{ SEE } & \multirow[t]{2}{*}{ D.W } \\
\hline & & & APS & GDP & FAID & Time & & & & \\
\hline 1.18 & $\mathrm{M}$ & -5178.72 & $\begin{array}{l}0.308 \\
(0.005) \\
58.40 * * *\end{array}$ & & & & 0.992 & 3410.7 & 3796.5 & 2.1 \\
\hline 1.19 & $\mathrm{M}$ & -4743.52 & $\begin{array}{l}0.619 \\
(0.079) \\
7.8 * * * \\
\end{array}$ & $\begin{array}{l}-0.307 \\
(-0.078) \\
-3.919 * * * \\
\end{array}$ & & & 0.995 & 2619.7 & 3067.6 & 2.1 \\
\hline 1.20 & $\mathrm{M}$ & -3898.09 & $\begin{array}{l}0.760 \\
(0.070) \\
10.92 * * *\end{array}$ & $\begin{array}{l}-0.484 \\
(0.073) \\
-6.609 * * *\end{array}$ & $\begin{array}{l}0.978 \\
(0.227) \\
4.299 * * *\end{array}$ & & 0.997 & 2926.5 & 2372.3 & 2.1 \\
\hline 1.21 & $\mathrm{M}$ & -785.19 & $\begin{array}{l}0.761 \\
(0.055) \\
13.78 * * * \\
\end{array}$ & $\begin{array}{l}-0.453 \\
(0.059) \\
-7.72 * * * \\
\end{array}$ & $\begin{array}{l}0.883 \\
(0.182) \\
4.85 * * * \\
\end{array}$ & $\begin{array}{l}-485.19 \\
(122.11) \\
-3.97 * * * \\
\end{array}$ & 0.998 & 3497.1 & 1880.4 & 2.1 \\
\hline
\end{tabular}

Notes: Figures in parentheses and asterisk state the same meanings as explained in Table.1 
The results explicitly state that Aggregate Private Spending (APS) and foreign aid (FAID) are significant at 1 per cent level of significance throughout the equations in Table 2. It highlights that aggregate private spending and foreign aid both have positive and significant role in raising the imports of Nepal. Contrary to this, GDP and the time factors seem to be significant with negative sign. All the factors are found to be working according to the hypotheses. One may justify now that raising GDP is the most pertinent policy to be adopted by Nepal. The exclusion of the ratio of government development expenditure to GDP means that government development expenditure excessively contains the non-productive and recurring expenditure. The RPI on the other hand, however, seems to be negatively significant at 1 per cent level of significance in the single equation system ${ }^{\mathbf{1 9}}$ the forward criterion method itself removed due to low tolerance factor. However, with time, the coefficient of relative price index (-1.6 p.c.p.a $)^{\mathbf{2 0}}$ is negatively significant at 1 per cent level of significance, the whole sale price index of India (WPIi) is positively associated to time by 7.5 pc.pa ${ }^{21}$. Instead, the time variable is being accepted that exhibits a declining trend in imports as time passes on. This shows that substitution between the Indian and Nepalese goods through the price effect are unimportant for Nepal. Satisfactory DW, 99 per cent of the explained percent of variation, and all other statistics except the SEE justified the greater extent of the validity of the model. Therefore, the aforementioned analysis of the model help to deduce the fact that the aggregate private spending and the amount of the foreign aid are the most pertinent predictors that raise the amount of imports to Nepal.

Though the equation on constant prices has also been run with forward criterion method, and the derived results are according to the proposed hypotheses, inconclusive d-w persists. The explanatory power of the model is good enough (99\%). At the same time, low SEE confirms the validity of the model. Aggregate private spending, GDP and FAID all confer significant role in determining the imports level of Nepal. Results of the equation 1.22 thus, indicate that all the independents play substantial role in expanding imports of Nepal.

$$
\begin{aligned}
& \mathrm{Mr}=-2452.62+0.78 \mathrm{APSr}-0.48 \mathrm{GDPr}+0.655 \mathrm{FAIDr} \quad \ldots \quad \ldots \quad \ldots(1.22) \\
& \begin{array}{lll}
(.055) \quad(0.06) \quad(0.21)
\end{array} \\
& 14.14 * * * \quad-7.83 * * * \quad 3.07 * * * \\
& \mathrm{R}^{2}=0.995, \mathrm{~F}=1549.7, \mathrm{SEE}=316.97, \mathrm{DW}=1.6
\end{aligned}
$$

Furthermore, an effort is made to test the import function in the log-linear form by applying the aforementioned variables but the results in demonstration have not been significantly different. The $\mathrm{X}$ - ray scrutiny of the model too has delineated the truth that aggregate private spending seems to be the important import-increasing factor than to the ratio of development expenditure to GDP and the relative price index.

\section{Summary and Conclusions}

The effects of export expansion to economic growth are observed by applying a number of models in both constant and current prices. In the course of analysis, most models of current

\footnotetext{
$\overline{{ }^{19} \mathrm{M}=270586.2-277670 \text { RPI } \ldots \mathrm{R}^{2}=0.64 \text {, see }}=25690.7, \mathrm{~F}=48.07, \mathrm{DW}=0.282$ $-6.934 * * *$

${ }^{20} \mathrm{RPI}=1.048048(\mathrm{~T})^{0.984}$

${ }^{21} \mathrm{WPIi}=84.448(\mathrm{~T})^{\mathbf{1 . 0 7 8}}$
} 


\section{The Journal of Nepalese Business Studies}

price data are found valid rather than the models of constant price data. Various forms of the models like, linear, log-linear, Cobb-Douglas and growth rate are applied where capital, labor and export have been observed significant in both linear and log-linear forms. Moreover, the same factors however showed less validity and reliability of the model when fitted in growth rate form. At the same time growth rate of labor has remained negative and insignificant but capital has remained positive with insignificant t-value. Contrary to this, export is positive as well as highly significant. Replacement of export to manufactured export, the degree of association further comes down. The inclusion of average propensity to invest, the product of export growth and ratio of exports to GDP $\left(\mathrm{XG}_{\mathrm{r}}\right)$ raised the explained per cent of variation. The propensity to invest has remained as insignificant where as $\mathrm{XGr}$ is positive as well as significant. The replacement of capital to saving remains insignificant with positive sign.

The models in linear, log-linear and in the first difference form, all have justified that along with labor and capital, export expansion is also the major determining factor for raising per capita income of Nepal. In regard to import function, among various independents, APS and FAID are the most import increasing factors.

To sum up, the results justify exports growth leads to economic growth. Private spending is the most import-increasing factor than government spending. The remarkable conclusion that may be drawn is that the substitution between the Indian goods and Nepalese goods through price effect is highly considerable.

From the foregoing discussion, following suggestions require careful consideration for policy formulation. Nepal's foreign trade has tremendously been suffering from successive deficit which can have negative effect on foreign currency reserve of the country and thereby invite macro economic instability. Inefficient management of the growing population may invite disaster to the economic growth of country in long run. The import substitution policy demands an overall evaluation so that industries only competitive in the international markets are selected for promotion. Therefore, government should encourage the policy of adequate investment in export oriented industries that embodies a 'proper mix' of export promotion and import substitutions.

\section{REFERENCES}

Ahluwalia, M. S., Nicholas G. Carter, and Hollis B. Chenery 1979. Growth \& Poverty in Developing Countries, Journal of Development Economics. Sept.16: 298-323.

Balassa, Bela 1985. Exports, Policy Choices, and Economic Growth in Developing Countries After the 1973 Oil Shock. Journal of Development Economics. 18: 23-35.

Barkey, R. M. 1982. National Accounting with Limited Data. Lessons from Nepal. Review of Income and Wealth Series. Sept. 28(3): 395-405.

Baron, P. 1957 The political Economy of Growth. New York: Monthly Review Press.

CBS (1996). Nepal Living Standards Survey Report 1996. Vol. 2, NPC:

Chacholiades, Miltiades 1978. International Trade Theory \& Policy. Mexico: MCGRAW-Hill International Book Company.

Davis, Kenneth K. 1985. International Economics. Fifth Edition. New York: John Willey and Sons.

Devkota, Satis C. 2000. Exchange Rate Change and Its Impact on Foreign Trade Balance in Nepal. The Economic Journal of Nepal. Jan.-Mar.23(1): 23-33.

Edwards, Sebastian 1993. Openness, Trade Liberalization, and Growth in Developing Countries. Journal of Economic Literature.Sept.31: 1358 - 1393. 


\section{Foreign Trade and its effects on Nepalese Economic Development}

Feder, Gershon 1983. On Exports and Economic Growth: Journal of Development Economics. Feb./Apr.12 (12): 59-73.

Garanja, M.B. 2000. A Note on Prospect of Balance of Trade of Nepal. The Economic Journal of Nepal.OctDec.23 (4): 203-8.

Gray, Patricia and Hans W. Singer 1988. Trade Policy and Growth of Developing Countries: Some Data. World Development. 16(3): 395-403.

Gujarati, Damodar 1978. Basic Econometrics. Tokyo, Mc Graw Hill Ltd.

Habeler, Gottfried 1956. International Trade and Economic Development. London: Italics mine.

Higgins, Benjamin 1999. Economic Development, Problems, Principles \& Policies. Revised Edition. New Delhi: Universal Book Stall.

Hussain, Aktar 1996. Macro Economic Issues and Policies: The case of Bangladesh. New Delhi /Thousands oak/London: Sage publication.

Kavoussi, Rostam M. 1984. Export Expansion and Economic Growth: Further Empirical Evidence. Journal of Development Economics. Jan/Feb. 14(1-2): 241-50.

Kohli, Inderjit and Nirvikar Singh 1989. Exports and Growth: Critical Minimum Effort and Diminishing Returns. Journal of Development Economics. Apr. 30(2): 391-400

Krueger, Anne O. 1978. Foreign Trade Regimes and Economic Development: Liberalization Attempt and Consequences. Cambridge: Ballinger Publication Co. for NBER.

Kuznet, Simon 1955. Economic Growth and Income Inequality, American Economic Review, March.45 (1): 128.

Leibenstein, Harvey 1957. Investment Criteria, Productivity, and Economic Development. Quarterly Journal of Economics. Aug. 343-370.

Leontif, W. et al. 1953. Studies in the Structure of the American Economy. New York: Oxford University Press.

Lewis, Arthur W. 1961. The Theory of Economic Growth. Fifth Edition. London: George Allen \& Unwill Ltd.

Ligal, Prithivi R. 1983. An Analysis of Government Expenditure and Its Impact on Imports, Money Supply and Prices in Nepal. The Economic Journal of Nepal. July-Sept.6 (3): 56-74.

Marx, Karl 1977. Karl Marx selected Writing, London: Oxford University Press ed. MCLELLAN, David.

Meade, James E. 1972. The Theory of International Economic Policy: Trade \& Welfare. The Great Britain: The English Language Book Society.

Meier, Gerald M. 1963. International Trade \& Development. New York: HAPPER International Edition.

Meier, Gerald M. 1975. Leading Issues in Economic Development. Third Edition. New York: Oxford University Press.

Meier, Gerald M. and R. E. Baldwin 1960. Economic Development: Theory History Policy. First Edition. Bombay: Asia Publishing House.

Morris D. Morris 1979. Measuring the Condition of the World's Poor: The Physical Quality of Life Index, London: Cass.

Pant, Bhubnesh 1994. Trade and Development, Nepal's Experiences. New Delhi: Oxford and IBM Publishing Co. Pvt. Ltd.

Perbisch, Raul 1950. The Economic Development of Latin America. New York: United Nations.

Pokherel, Keshab 1982. Pattern of Nepal's foreign trade with overseas Countries. An Unpublished Master Thesis. T.U., Kirtipur.

Poudel, Sri R. 1998. Foreign Trade, Aid and Development in Nepal. New Delhi: Common Wealth Publishers.

Poudyal, Shoora B. 1998. Foreign Trade and Economic Growth. Tribhuvan University Journal. June 11(1):11723.

Ram, Rati 1985. Export and Economic Growth: Some Additional Evidence. Economic Development and Cultural Change. Jan. 36(1): 415-25.

Ram, Rati 1987. Export and Economic Growth in Developing Countries: EvidenceFrom Time Series and CrossSectional Data. Economic Development and Cultural Change. Oct. 36(1):51-72.

Rana, Pradumna B. 1988. Exports, Policy Changes and Economic Growth in Developing Countries after 1973 Oil Shock: Comments. Journal of Development Economics. Mar. 28(2):261-64.

Regmi, Udaya R. 1998. Export and growth: The Nepalese Case. The Economic Journal of Nepal. July-sept.21 (3): $149-57$.

Ricardo, David 1817. Principles of Political Economy and Taxation. London: Everyman.

Roll, Eric 1973. History of Economic Thought. Fourth Edition. London: Faber and Faber Ltd. 


\section{The Journal of Nepalese Business Studies}

Selltitz, C., L.S. Writsman and S.W. Cook 1976. Research Methods in Social Sciences. New Delhi: Holt, Renehart \& Wingston.

Shrestha, Narayan B. 1981, Foreign Trade and Economic Development. An Unpublished Master Thesis. T.U., Kirtipur.

Shrestha, S.K. 1994. Export Market Management in Nepal-A critical study. Kathmandu: Padma Educational Traders.

Singer, Hans W. 1950. The Distribution of Gains between Investing and Borrowing Countries. American Economic Review. May.40 (2): 473-85.

Smith, Adam 1976. An Inquiry into the Nature and Causes of Wealth of Nation. New York: (ed.) Edwin Cannan. Oxford University Press.

Thirlwall, A. P. 1999. Growth and Development. Sixth Edition. London: Macmillan Press.

Todaro, Micheal P. 1997. Economic Development. London, U.K.: Addison Wesley Longman Limited.

Tyler, William 1981. Growth and Export Expansion in Developing Countries: Some Empirical Evidence. Journal of Development Economic.Aug.9 (1): 121-130.

Tyler, William 1999. World development indicators. World Development Report 1999/00. Washinton D.C.: The World Bank.

Tyler, William 2003. World Development Report, 2003. Washington D.C.: The World Bank.

Viner, Jacob 1977. The Economics of Development: in the Economics of Underdevelopment. Second Edition. London: (ed) A. N. Aggarwal and S. P. Sing. Oxford University Press. 